\title{
A framework for organizing participatory Water Planning and Management Team (WPMT)
}

\author{
Mohammad Salarian ${ }^{1}$, Kamran Davary*2, Amin Alizadeh ${ }^{3}$, Mohammad Lagzian ${ }^{4}$ and \\ Mohammad Fazeli ${ }^{5}$ \\ ${ }^{1}$ Ph.D. student of Water Engineering, Irrigation and Drainage, Ferdowsi University of Mashhad \\ ${ }^{2}$ Professor of Water Engineering, Irrigation and Drainage, Ferdowsi University of Mashhad. \\ Corresponding Author: k.davary@um.ac.ir \\ ${ }^{3}$ Professor of Water Engineering, Irrigation and Drainage, Ferdowsi University of Mashhad \\ ${ }^{4}$ Professor of Management Department, Ferdowsi University of Mashhad \\ ${ }^{5}$ Assistant Professor of the Faculty of Literature and Humanities, ShahidBeheshti University
}

\begin{abstract}
The need to properly manage water resources has become increasingly important as states strive to improve their socio-economic and social-ecological situation.No actor can be expected to understand sufficiently the multiple interdependent physical, ecological, social, cultural and political processes that govern the behavior of water resources systems.Broad-scale, multi-governance level, participatory water management processes intended to aid collective decision making and learning are rarely initiated, designed, implemented, and managed by one actor. Participatory water management processes mostly emerge from some form of collective planning and organization activities because of the stakes, time, and budgets involved in their implementation. Despite the potential importance of these collective processes for managing complex water-related social-ecological systems, little research focusing on the projectteams that design and organize participatory water management processes has ever been undertaken. In this text we have begun to fill this gap by introducing and outlining the concept of a participatory processbyreview previous studies. The analyticalframework suggested in this text is organized around eight components; Who are Stakeholders, Drivers of stakeholder engagement in the water sector, Stakeholder Analysis, Stakeholders' interactions, Level of participation, Organizational structure, When stakeholder engagement and effective participatory processes.
\end{abstract}

Key word: Social, Cultural, Ecological, Collective, Stakeholders, Actor

\section{Introduction}

Public participation around the world has been part of a wide range of environmental applications including integrated watershed management (Sabatier et al., 2005; ISPWDK, 2005; Kenney et al., 2000), agricultural development (Wilson, 2004), ecosystem management (Knight et al., 2006), environmental governance (Rist et al., 2007), forest management (Buttoud and Yunusova, 2002; Carter and Gronow, 2005) and planning (Buchy and Hoverman, 2000; Buchecker et al., 2003). Participation typically refers to the engagement and involvement ofindividuals and groups in the design, implementation and evaluation of a project or plan (OECD, 2015).The rapidly expanding literature on participatoryapproaches in various domains of water sector (Pereira et al., 2003; Mostert 2006) shows a tremendous diversity in purpose, process design, and implementation (Von Korff et al., 2005). The academic debate typically focuses on what to do or analyze (Walker et al., 2002), who to involve (Fung 2006), or how to adapt to the local context (Miettinen and Virkkunen 2005, D’Aquino 2009).The literature provides a wide range of case studies illustrating the advantages of participation. Advantages of participation are: Better trust in decisions (Richards et al., 2004; Beirle, 2000); Improving project design using local knowledge (Irvin and Stansbury, 2004; Habron, 2003; Beierle and Cayford, 2002); Better understanding projects and issues (Duram and Brown, 1999); Integration of various interests and opinions (Griffin, 1999; Creighton, 1986); Optimizing implementation of plans and projects (Konisky and Beierle, 2001); Public acceptance of the decisions (Reed, 2008; Junker et al., 2007); Fostering and developing social learning (Blackstock et al., 2007; Pahl-Wostl, 2002). In addition, a number of clear principles for successful participation can be identified, including: A fair, equal, and transparent process that promotes equity, learning, trust and respect among stakeholders and the administration (Reed, 2008;Webler et al., 2001; Moote et al., 1997); The integration of local and scientific knowledge (Reed, 2008; Tippett et al., 2007); The establishment of rules in advance (Sabatier et al., 2005; Renn et al., 1995); An early involvement of stakeholders (Leach et al., 2002; Leach and Pelkey, 2001); The integration of all stakeholders (Smith Korfmacher, 2001); The presence of experienced moderators (Leach et al., 2002), and Adequate resources, including time (Leach and Pelkey, 2001; Keeney et al., 2000).Stakeholder engagement holds specific importance in water because this is a highlydecentralized and fragmented sector, with multiple, interdependent players at differentlevels.The traditional role of governments as the single decision-making authority hasgradually been replaced by multi- 
level, polycentric governance demonstrating that aplethora of stakeholders can contribute to and better guide decision making. Water isaffected by numerous external drivers and influences many other policy areas that arecritical for economic development and well-being, including health, agriculture, land-useand spatial planning, poverty alleviation and energy. These policy areas tend to work insilos and further improvement is often needed in terms of consultation, participation andco-ordination to engage stakeholders in a coherent, holistic and integrated way (OECD, 2015).Formalizing, or even institutionalizingcollective decision making related to water issues requires strong leadership commitmentwith clear objectives and strategies to prevent and manage risks of capture. It alsoimplies securing the needed financial and human resources at the appropriate levels tosustain the engagement process.Because there are more and more actors in the water sector willing to take part in discussions to influence certain decisions, it is crucial to evaluate regularly the actualweight and value-added of stakeholder engagement in water-related decision making andpolicy or project implementation, and its contribution to better governance. Stakeholder analysis can be used for the preparation and evaluation of projects (ODA, 1995; Grimble and Chan, 1995), for the facilitation of stakeholder involvement in participatory projects or in cooperative resource management (MacArthur, 1997), for strategy development by project managers to assure the implementation soundness of projects or policies (Varvasovszky and Brugha, 2000), for understanding the general issues related to conservation and degradation of natural resources (Grimble and Wellard, 1997), and for a comprehensive analysis to understand better past policy making processes or to assist in formulating new policies (Varvasovszky and Brugha, 2000).

This research have been broken down into a number of component parts. It emphasizes that the stakeholders should first be identified and analyzed, that their interests and expectations should be understood, and that their level of power and influence should be understood as well. A plan for stakeholders' interaction, mapping stakeholders, time of stakeholder engagement in participatory modeling process and effective participatory processes has been outlined.

\section{Public/ Stakeholder Participation}

Publicparticipation is constituted of forums for exchange that areorganized for the purpose of facilitating communication betweengovernment, stakeholders and interest groups regarding a specific decision or problem (Rennet al., 1995). Public participation is two way communication and collaborative problem solving with the goal of achieving better and more acceptable decisions. Public participation prevents or minimizes disputes by creating a process for resolving issues before they become polarized. Public participation is intended to both inform the public and to be informed by them by actively soliciting public response regarding their problems, needs, and values, ideas about solutions, and reactions to proposed solutions to problems. A public participation program has to provide people from diverse backgrounds and interests multiple opportunities to ask questions and offer suggestions. The public participation program has to be responsive to public concerns, though this need not mean acting favorably on everything the public says. There are three primary goals of public participation: 1) Credibility: An open and visible decision-making process accessible to all on an equal basis makes the planning process credible to groups with diverging points of view; 2) Identifying Public Concerns and Values: various groups have different points of view and values, they will evaluate any proposed action from different perspectives. Public participation allows the planning team to understand the problems, issues, and possible solutions from the perspectives of the various interests; 3 ) developing a Consensus: An implication of the many divergent points of view is that there is no one philosophy that can guide the planning team's decisions. Consensus must be formed on an issue by issue basis. Public participation provides a process for evolving such consensus. Consensus, then, allows the team to move forward and solve the problem. If the public is not involved from early in the planning process, if participation never results in any tangible change, if the alternatives considered are only the ones the partners want, the public will get the message "we're going through the motions of public participation; don't expect anything to come of it.” Good public participation is much more than "letterofthelaw" involvement (Charles and Kenneth, 1996). Other terms sometimes used are "public involvement," "community involvement," or "stakeholder involvement” (IAP2, 2007).

Distinctions are often made between the public and the stakeholdersparticipation.In the literature however, these terms are not usedconsistently and may confuse rather than clarify understanding.The public is often considered as a collection of individuals generallyunstructured and unorganized (Luyet, 2005). Onthe other hand, stakeholder can be defined as "any group of peopleorganized, who share a common interest or stake in a particularissue or system" (Grimble and Wellard, 1997). In this paper, weconsider the public as one specific stakeholder and therefore weuse the term "stakeholder participation" (Kessler, 2004) rather than publicparticipation.

\section{Who are Stakeholders}

Terms such as 'Stakeholder' and 'Actor' have become ubiquitous in water resources management (WRM), with analyses of them constituting essential components to decision-making processes. Although several definitions for these concepts exist, generally both terms are used interchangeably and encompass any group or individual who is affected by or who has an ability to significantly influence (either directly or indirectly) an action or 
policy (Bryson, 2004). However, some definitions restrict the term 'actor' to a subset of stakeholders comprising exclusively those interested parties with the power and agency to affect action or policy outcomes (Enserink et al., 2010). Stakeholders are considered as people, institutions or organizationsthat have a stake in the outcome of decisions related towater management, as they are directly affected by the decisions made or have the power to influence the decision making process (Nandalal and Simonovic, 2003). The term 'stakeholder' is often interchanged with 'the community', however this is technically incorrect. The community can refer to people within a specific location, or with a specific interest. A community is a subset of all the actors and the actors a subset of the stakeholders, as shown in Figure 1.

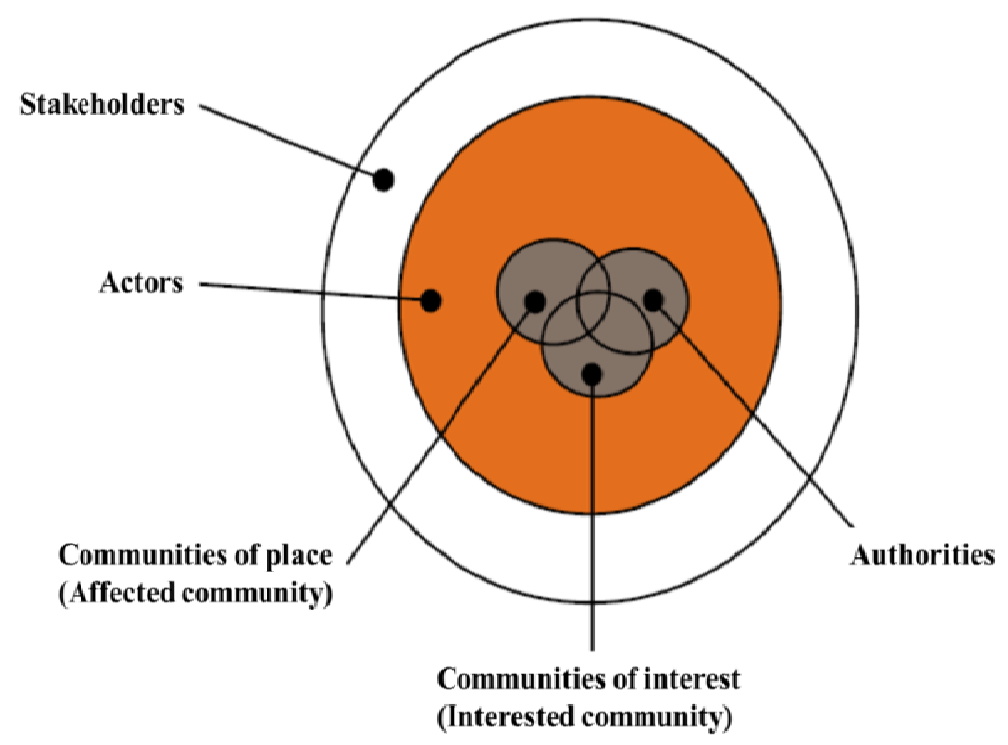

Figure 1. Relationship between stakeholders, actors and communities

\section{Water PlanningTeam}

The composition of a study team is a critical step in determining the water planning effort's ultimate effectiveness. Teams just don't happen; they're built. Team building is thedeliberate process of creating a successful team from among a group of stakeholder.The composition of the team depends on the nature of the water planning effort. While the mix of disciplines required for a team varies from study to study.

\section{Drivers of stakeholder engagementin the water sector}

The water outlook is not optimistic, and future economic, social, climate, urban and technological trends challenge water governance and the capacity of governments to address them, often calling for multistakeholder solutions. By 2050, the world's population is projected to grow to around 9 billion people, with a major proportion living in urban areas. A total of 4 billion people will live in water-stressed areas, and water demand will increase by 55\%, thus generating further competition among water users (especially domestic, hydropower and irrigation) (OECD, 2012).

Pressure points over water allocation, infrastructure financing and disaster management will require doing better and more with more stakeholders willing to contribute to finding innovative solutions. Four main purposes for water decision makers to engage stakeholders are: 1) Implement normative principles, 2) Improve the quality of decision outcomes, 3) Generate legitimacy in the process and 4) Solve water related conflicts (Glucker et al., 2013). The first function is rooted in democratic principles and concerns engagement that derives from the people's right to be informed. Examples include informative meetings to raise awareness on specific water issues, such as drinking water standards, tariffs and aquifer depletion, without necessarily looking for inputs to decision making. The second function refers to situations where stakeholders may contribute by providing decision makers with key information and knowledge. The third case implies that through engagement, stakeholders develop a sense of ownership over the process and its outcomes, and tend to consider it more legitimate. The fourth case shows that inclusive approaches can also contribute to identifying and resolving water-related conflicts before final decisions are taken, and facilitating project and policy implementation.The future gloomy picture for the water sector has triggered new emphasis on the role of stakeholder engagement across public, private and non-profit sectors, combined with structural and conjunctural drivers that have pushed stakeholder engagement to develop along different rationales, these drivers showed in Figure 2. 


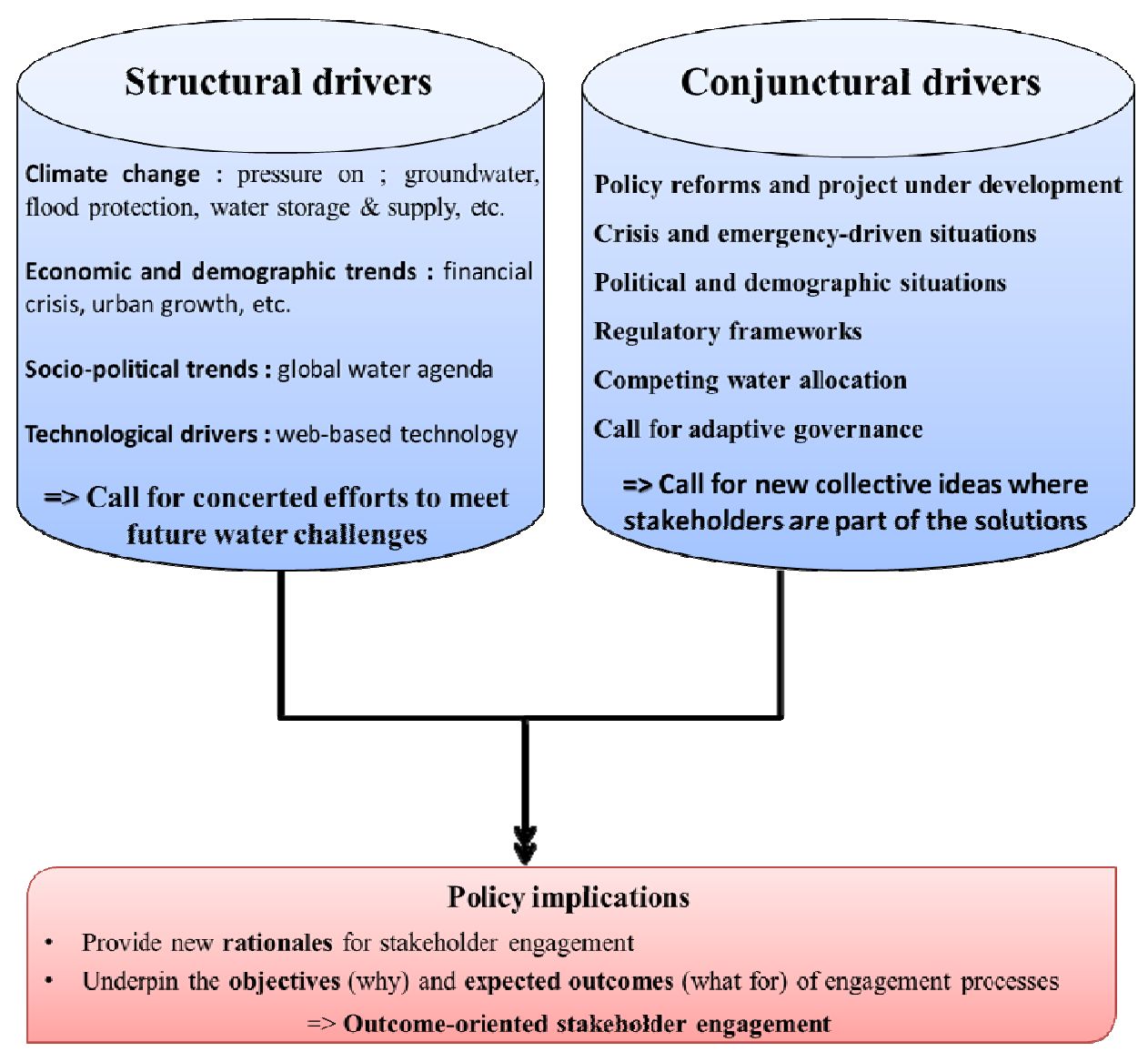

Figure 2. Drivers of stakeholder engagement in the water sector (OECD, 2015)

\section{Stakeholder Analysis}

A stakeholder analysis is a process, which provides insights into, and understanding of, the interaction between a project and its stakeholders. Stakeholder analysis systematically gathers and analyzes both qualitative and quantitative information thereby to determine whose interest should be taken into account throughout the project (Pandi-Perumalet al., 2015).

Despite their wide range, the different applications of stakeholder analysis have more in common than just a focus on stakeholders' interests. The different overview articles all describe stakeholder analysis procedures that follow similar steps. In some reviews only a few steps are covered, while in other articles the authors discuss some steps in more detail than others. Taken together the body of literature on stakeholder analysis offers a useful overview of guidelines and Known pitfalls for each step. A general outline of the different steps is presented in Table 1. 
Table 1. Procedure for stakeholder analysis

\begin{tabular}{|c|c|c|}
\hline Grimble\& Chan, 1995 & MacArthur, 1997 & Varvasovszky\&Brugha, 2000 \\
\hline \multicolumn{3}{|c|}{ General purpose of stakeholder analysis } \\
\hline $\begin{array}{l}\text { Dealing with and understanding } \\
\text { natural resource management } \\
\text { issues }\end{array}$ & $\begin{array}{l}\begin{array}{l}\text { Support in project planning } \\
\text { situations } \\
\text { projects) }\end{array} \\
\text { (for development }\end{array}$ & $\begin{array}{l}\text { Understand how policies have } \\
\text { developed \& assess feasibility } \\
\text { future directions }\end{array}$ \\
\hline \multicolumn{3}{|c|}{ 1. Define purpose, questions and conditions for actor analysis } \\
\hline Identify mainpurpose ofanalysis & $\begin{array}{l}\text { Define higherobjectives } \\
\text { ofproject concerned }\end{array}$ & $\begin{array}{l}\text { Identify aim andtime } \\
\text { dimensionof analysis }\end{array}$ \\
\hline \multicolumn{3}{|c|}{ 2. Preliminary scan of actor network and practical preparation } \\
\hline $\begin{array}{l}\text { Developunderstandingof system } \\
\text { anddecision makers }\end{array}$ & & $\begin{array}{l}\text { Assess culture,context, level } \\
\text { ofanalysis. Formanalysis team }\end{array}$ \\
\hline \multicolumn{3}{|l|}{ 3. Identify stakeholders } \\
\hline Identifyprincipalstakeholders & List thestakeholders & $\begin{array}{l}\text { Identify } \\
\text { andapproachstakeholders }\end{array}$ \\
\hline \multicolumn{3}{|l|}{ 4. Collect primary input data } \\
\hline $\begin{array}{l}\text { Investigatestakeholderinterests } \\
\text { \& characteristics data collection }\end{array}$ & $\begin{array}{l}\text { Determineinterests } \\
\text { ofstakeholders } \\
\text { objectives }\end{array}$ & $\begin{array}{l}\text { Data collectionusing interviews } \\
\text { and secondarysources }\end{array}$ \\
\hline \multicolumn{3}{|l|}{ 5. Structure and analyse data } \\
\hline $\begin{array}{l}\text { Identify patternsand contexts } \\
\text { ofstakeholders'interactions }\end{array}$ & $\begin{array}{l}\text { Assessstakeholders'importance } \\
\text { toproject objectivesAssess } \\
\text { power ofstakeholder toinfluence } \\
\text { projectoutcome }\end{array}$ & $\begin{array}{l}\text { Organize andanalyse } \\
\text { dataPresentfindings, } \\
\text { usingtablesandmatrices }\end{array}$ \\
\hline \multicolumn{3}{|c|}{ 6. Interpretation of results and translation into stakeholder management strategies } \\
\hline $\begin{array}{l}\text { Options } \\
\text { formanagingstakeholdersand } \\
\text { conflicts }\end{array}$ & $\begin{array}{l}\text { Consider whetheradditions } \\
\text { toproject design } \\
\text { arerequiredConsider } \\
\text { whichstakeholderinterests } \\
\text { shouldbe allowed forduring } \\
\text { differentproject stages }\end{array}$ & $\begin{array}{l}\text { Determinestrategies } \\
\text { formanagingstakeholders }\end{array}$ \\
\hline
\end{tabular}

\section{Stakeholder profiling}

Stakeholder profiles help to learn as much as possible about the stakeholder and to develop a strong understanding of them (either individuals or representatives of a community group). Factors to consider when developing a stakeholder profile are; Current views, Stakeholders' expectations, Knowledge of the issue, Legitimacy of stakeholder representation, Willingness to engage, Possible impacts (negative or positive) of the stakeholder, Cultural context, Geographical scale at which they operate, Stakeholder's engagement capacity and Relationships of stakeholders with each other. Using a stakeholder profile template can help collate the necessary information to make informed comparisons and decisions regarding who to involve and how best to involve them. While an individual operational-level engagement process is unlikely to use an extensive stakeholder profiling process, it could be beneficial to inform the numerous smaller processes that occur within water management activities.

\section{Prioritizing stakeholders}

A common method of prioritizing stakeholders is to focus on those stakeholders with the most influence on the goals and objectives of the participatory process and those most affected by the proposed water management activities. This enables scarce engagement resources to be utilised more effectively, concentrating on achieving the necessary strategic and operational outcomes. Impacted and influential stakeholders are treated with respect and given opportunities to understand the proposed activities, share concerns and help develop mutually acceptable solutions. 


\section{Stakeholders' interactions}

Understanding how stakeholders interact and the connectivity dynamics is important to assess their level of influence and engagement in water-related decision making and implementation. Stakeholders cannot be viewed in isolation but as embedded in webs of interrelations. They operate in formal and informal settings, with interactions of different nature, degree and frequency. Depending on their responsibilities and interests, stakeholders interact more or less often with one another. Social network analysis can provide a reading template to understand interactions between water actors (Fliervoet et al., 2016). It consists in applying network theory to analyses social networks. It views relationships in terms of nodes, representing each stakeholder within the network, and ties, which represent their interrelation. Social network analysis can help to evaluate the location of stakeholders in a network to find the centrality of each actor (i.e. the degree to which stakeholders are located close to the center of the social network thus the extent to which they are well-connected). As such, it can provide insight into the various roles and groupings of stakeholders in the water sector: which actors are leading, which actors are connecting and which actors are isolated. It can also identify clusters of stakeholders, and who is in them, as well as which actors are in the core of the network and which are on the periphery.

\section{How Stakeholder Participate}

The question of how to involve stakeholders in water resources management activities in order to achieve participatory benefits rests upon two fundamental considerations. The first relates to the level of participation that stakeholders experience, whilst the second concerns the organisational structure of that participation. Regarding the first consideration, various typologies have been developed that classify participation according to its degree of involvement or level of stakeholder commitment (Table 2). Arnstein (1969) was one of the first to develop such a typology, with her original eight-rung 'Ladder of Citizen Participation', but this has since been adapted by various scholars. Determining the appropriate level of participation is only one issue facing practitioners when engaging stakeholders. Another concern relates to the manner in which to structure such participation, particularly in those instances when large numbers of stakeholders need to be engaged in participatory planning activities.

Table 2:Various typologies model of participation

\begin{tabular}{lll}
\hline Models of Participation & Author & Year \\
\hline Ladder of citizen participation & Sherry Arnstein & 1969 \\
\hline Ladder of children participation & Roger Hart & 1992 \\
\hline Typology of participation & Sarah White & 1996 \\
\hline Degrees of participation & Phil Treseder & 1997 \\
\hline Wheel of participation & Scott Davidson & 1998 \\
\hline Active participation framework & OECD & 2001 \\
\hline Pathways to participation & Harry Shier & 2001 \\
\hline Clarity model of participation & Clare Lardner & 2001 \\
\hline Strategic approach to participation & UNICEF & 2001 \\
\hline Triangle of youth participation & De Backer and Jans & 2002 \\
\hline Youth participation in society & De Backer and Jans & 2002 \\
\hline Dimensions of youth participation & David Driskell & 2002 \\
\hline Seven realms of participation & Francis \& Lorenzo & 2002 \\
\hline Ladder of volunteer participation & Adam Fletcher & 2003 \\
\hline Challenge of public participation & Mostert & 2003 \\
\hline Four Cs of online participation & Derek Wenmoth & 2006 \\
\hline Power law of participation & Ross Mayfield & 2006 \\
\hline Levels, spaces and forms of power & John Gaventa & 2006 \\
\hline The CLEAR Participation Model & Lawndes\& Pratchett & 2006 \\
\hline Participation 2.0 Model & New Zealand & 2007 \\
\hline Engagement in the policy cycle & Diane Warburton & 2007 \\
\hline Online Participation Behaviour & Chain Fogg \&Eckles & 2007 \\
\hline Key dimensions of participation & Driskell\&Neema & 2009 \\
\hline Matrix of participation & Tim Davies & 2009 \\
\hline Pathways through participation & NCVO \& IVR & 2009 \\
\hline Changing views on participation & Pedro Martín & 2010 \\
\hline & &
\end{tabular}




\begin{tabular}{lll}
\hline Models of Participation & Author & Year \\
\hline Ladder of online participation & Bernoff\& Li & 2010 \\
\hline Online participation across age & Rick Wicklin & 2010 \\
\hline Three-lens approach to participation & DFID-CSO & 2010 \\
\hline Behavior Grid & Fogg & 2010 \\
\hline The Participation Tree & Harry Shier & 2010 \\
\hline Typology of Youth Participation & Wong & 2011 \\
\hline Six principles of online participation & Tim Davies & 2011 \\
\hline
\end{tabular}

Level of participation: The spectrum of stakeholder participation was designed by the International Association for Public Participation (IAP2) to assist with the selection of the level of participation that defines the stakeholder's role in any stakeholder participation process (IAP2, 2007). The spectrum shows that differing levels of participation are legitimate and depend on the goals, time frames, resources, and levels of concern in the decision to be made. The spectrum is essentially a matrix identifying the various levels of public participation. The levels of participation in the spectrum matrix include inform, consult, involve, collaborate and empower. Each level of stakeholder participation is chosen based on the specific goal of the project (Figure 3). Table 3 show the tools of stakeholder engagement for each level of participation in the spectrum matrix.

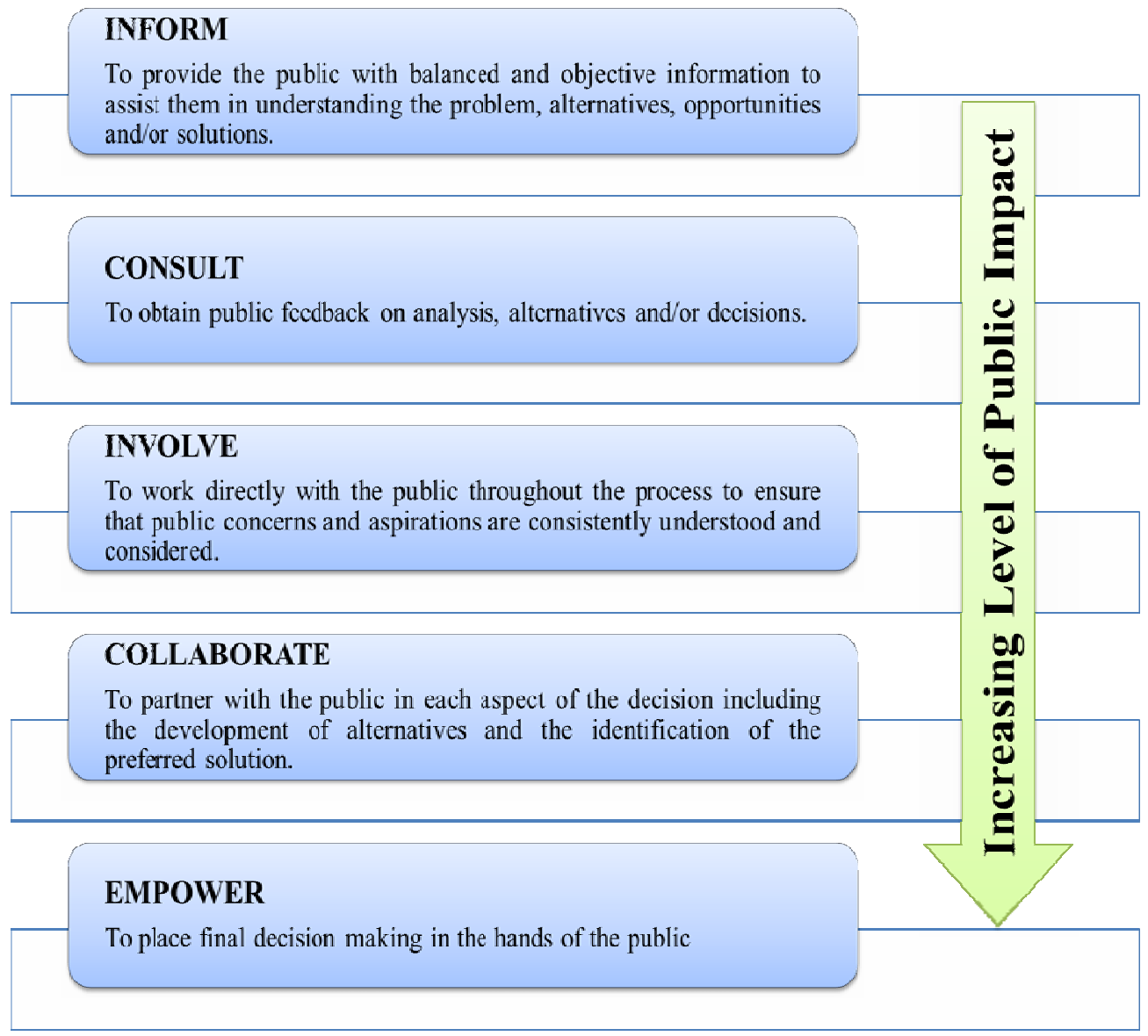

Figure 3. Spectrum Public/ stakeholder participation (IAP2, 2007) 
Table 3. Classifications of stakeholder engagement tool in the level of Inform, Consult, Involve, Collaborate and Empower (IAP2, 2009; Tippett et al., 2007; Richards et al., 2004; Van Asselt et al., 2001; Rowe and Frewer, 2000.)

\begin{tabular}{|c|c|c|c|c|c|}
\hline Tool & Inform & Consult & Involve & Collaborate & Empower \\
\hline \multicolumn{6}{|l|}{ Community fairs } \\
\hline \multicolumn{6}{|l|}{ Design charrettes } \\
\hline \multicolumn{6}{|l|}{ Information contacts } \\
\hline \multicolumn{6}{|l|}{ Information hotline } \\
\hline \multicolumn{6}{|l|}{ Information repository } \\
\hline \multicolumn{6}{|l|}{ Newsletter } \\
\hline \multicolumn{6}{|l|}{ Reports } \\
\hline \multicolumn{6}{|l|}{ Briefings } \\
\hline \multicolumn{6}{|l|}{ Civic journalism } \\
\hline \multicolumn{6}{|l|}{ Displays and exhibits } \\
\hline \multicolumn{6}{|l|}{ Field trips } \\
\hline \multicolumn{6}{|l|}{ Speak out (version 1) } \\
\hline \multicolumn{6}{|l|}{ Surveys } \\
\hline \multicolumn{6}{|l|}{ Technical reports and discussion papers } \\
\hline \multicolumn{6}{|l|}{ Telephone trees } \\
\hline \multicolumn{6}{|l|}{ Interactive TV } \\
\hline \multicolumn{6}{|l|}{ Printed information } \\
\hline \multicolumn{6}{|l|}{ Questionnaires and responses } \\
\hline \multicolumn{6}{|l|}{ Role plays } \\
\hline \multicolumn{6}{|l|}{ Shopfront } \\
\hline \multicolumn{6}{|l|}{ Citizen committees } \\
\hline \multicolumn{6}{|l|}{ Focus groups } \\
\hline Key stakeholder interviews & & & & & \\
\hline Fishbowl & & & & & \\
\hline Newspaper inserts & & & & & \\
\hline Poster competitions & & & & & \\
\hline Sketch interviews & & & & & \\
\hline Submissions & & & & & \\
\hline Snowball sampling & & & & & \\
\hline Photovoice & & & & & \\
\hline Electronic democracy & & & & & \\
\hline Open house & & & & & \\
\hline Web sites & & & & & \\
\hline Public involvement volunteers & & & & & \\
\hline Public meeting & & & & & \\
\hline Search conference & & & & & \\
\hline Participant observation & & & & & \\
\hline Future search conference & & & & & \\
\hline Consensus conference & & & & & \\
\hline Citizen juries & & & & & \\
\hline Study circles & & & & & \\
\hline Visioning & & & & & \\
\hline Workshops & & & & & \\
\hline Delphi study & & & & & \\
\hline Conference & & & & & \\
\hline Brainstorming & & & & & \\
\hline Prioritisation matrix & & & & & \\
\hline
\end{tabular}




\begin{tabular}{|c|c|c|c|c|}
\hline Tool & Inform & Consult & Involve Collaborate & Empower \\
\hline \multicolumn{5}{|l|}{ Community indicator } \\
\hline \multicolumn{5}{|l|}{$\begin{array}{l}\text { Multi Objective Decision-Making Support } \\
\text { (MODSS) }\end{array}$} \\
\hline \multicolumn{5}{|l|}{ Nominal group } \\
\hline \multicolumn{5}{|l|}{ Open space technology } \\
\hline \multicolumn{5}{|l|}{ Planning4real } \\
\hline \multicolumn{5}{|l|}{ Mediation and negotiation } \\
\hline \multicolumn{5}{|l|}{ Speakout (version 2) } \\
\hline \multicolumn{5}{|l|}{ Backcasting } \\
\hline \multicolumn{5}{|l|}{ Community profiling } \\
\hline \multicolumn{5}{|l|}{ Media releases } \\
\hline \multicolumn{5}{|l|}{ Mind maps } \\
\hline \multicolumn{5}{|l|}{ Samoan circles } \\
\hline \multicolumn{5}{|l|}{ Scenario testing } \\
\hline \multicolumn{5}{|l|}{ Simulation (electronically generated) } \\
\hline \multicolumn{5}{|l|}{ Stakeholder analysis (CLIP) } \\
\hline \multicolumn{5}{|l|}{ Stakeholder analysis (Stakeholder matrix) } \\
\hline \multicolumn{5}{|l|}{ Stakeholder analysis (Venn diagrams) } \\
\hline \multicolumn{5}{|l|}{ Technical assistance } \\
\hline \multicolumn{5}{|l|}{ Expert panel } \\
\hline Kitchen table discussion & & & & \\
\hline
\end{tabular}

Organisational structure: A useful way of structuring participation to limit numbers but not the influence of specific stakeholders is provided by the 'Circles of Influence (CI)' model, developed by sociologist Robert Waldman and now used by the US Army Corps of Engineers' (Werick\& Whipple, 1994).Thisapproach is similar to "Orbits of Participation" (IWR,2002). Under this model (Figure 4), trust is developed in concentric circles; planners and managers work to develop trust with leaders and organisations that other stakeholders already trust. The CI approach organizesstakeholders or subsets of the interested publicaccording to their interests and capability of understandingcomplex technical issues. This can be visualizedas a series of concentric circles. As anillustration, suppose there are four concentric circles,with Circle A being the innermost and Circle D beingthe outermost (Palmer et al., 2013). That is, those most directly involved in policy analysis activities (i.e. planners, managers and modellers who do most of the actual work; Circle A, communicate with trusted leaders and major stakeholder representatives at the next level (Circle B). These stakeholders then in turn provide a trusted link to all other interested parties, who have less direct involvement (Circle C). Ideally, Circle B participants would be active in professional or issues-oriented organisations and provide links to others whose interests they represent. Hence, Circle $\mathbf{C}$ stakeholders should see their interests represented in Circle B, and have formal opportunities to shape the work of Circles A and B via these representatives. Circle D contains political decision makers who provide direction to the efforts and activities of the other circles and receive information from those circles to support decision making. Politicians, their staffs, and appointed officials all may play roles in Circle D. It is important to note that communication is passed both throughout the circles (between members) and across circles (between groups of planning participants) and this information flows in all directions.

Mostert (2003), identifies six main levels of stakeholder participation in WRM, which include (in increasing order of involvement intensity):

\begin{tabular}{ll}
\hline $\begin{array}{l}\text { 1. Information } \\
\text { 2. Consultation }\end{array}$ & $\begin{array}{l}\text { Stakeholders simply receive information. } \\
\text { 3. Discussion }\end{array}$ \\
$\begin{array}{l}\text { Stakeholders provide information to policy advisors/makers. } \\
\text { A two-way interactive relationship between stakeholders and policy } \\
\text { advisors/makers. }\end{array}$ \\
$\begin{array}{l}\text { The active public involvement of stakeholders in problem analysis } \\
\text { and policy/project design. }\end{array}$ \\
$\begin{array}{l}\text { 5. Co-decision-making } \\
\text { 6. Independent decision-making }\end{array}$ \\
$\begin{array}{l}\text { The independent performance of planning/management tasks by all } \\
\text { stakeholders. }\end{array}$
\end{tabular}




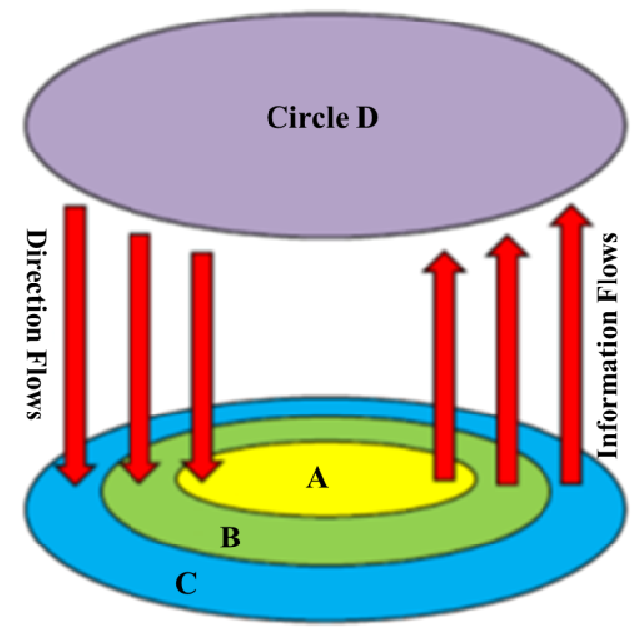
A: Directly involved Planners, Managers \& Modellers
B: Trusted Leaders \& Stakeholder Representatives
C: All Interested Parties
D: Decision-Makers

Figure 4. Circles of Influence Model (Werick\& Whipple, 1994)

The Circles of Influence model structure allows and encourages open communication throughout a participatory engagement process. Its proponents hold that this openness then helps develop trust amongst the different parties respect for each other's interests and values (Cardwell et al, 2009). Structuring participation in this way also lends itself to more easily define when and how each of the stakeholders situated within each circle is involved in specific participatory approaches. Combining the 'Circles of Influence' model with the typology of participatory levels of Mostert, one could hypothesize that participation at lower levels (1-3) would be most appropriate for Circle C stakeholders, whilst middle levels of participation (3-4) would be better suited to Circle B stakeholders working in cooperation with those in Circle A. Co-decision-making (Level 5) would likely see Circle B stakeholders collaborate with those in both Circles A and D. The top independent decision-making level (Level 6) is somewhat of a special case, in that stakeholders operating at this level would assume the role of Circle D entirely.Different stakeholders are involved in different phases of planning.

\section{When stakeholder engagement}

Stakeholder mapping is a stepping stone to understand how the water sector is organized in terms of functions and responsibilities and appropriately determine who should be engaged in decision making and implementation. Identifying stakeholders, the role they play and the influence they can have over water policies and projects processes is important to see beyond the traditional and, at times superficial, picture. An effective stakeholder mapping should help decision makers to investigate how roles are distributed, who are the key stakeholder categories, which one is pushing for what, and which ones are not being "heard" (like: Women, Young and Indigenous people, etc.)? In turn, it can support reflections on new ways to broaden the audience of engagement processes. In addition, it should not be assumed that all actors within one category are homogenous in their perceptions. Such perceptions depend on many factors - which need to be explored through the analysis - and each situation should be considered afresh rather than jumping to conclusions about the stand that different stakeholders are likely to take. Mapping exercises highlight the range of stakeholders that play a role in managing water, in terms of strategic planning, priority setting, allocation of uses, environmental regulation, information, monitoring, evaluation and level (from local to international). A typology of stakeholders can help clarify who they are, while a typology of water management function can help categorise what they do.

All stakeholders need to be informed of the various stages and outcomes of policyand project processes, but they do not need to be involved at each stage of the waterproject or policy. Engagement processes can be most effective when they include acareful and strategic selection of stakeholders that strikes a balance betweencomprehensive representation and a manageable number of participants. It is alsoimportant to take into consideration the timing of participation. Some stages of theprocess may be more suitable to certain stakeholder groups than to others.It is important to consider and discuss with stakeholders what they expect from theengagement process, and what could prevent them from participating. If eachstakeholder's motivations are clarified from the start, the risk of confusion is reduced andthe chance of greater satisfaction with the outcomes is increased. This is especiallyimportant for certain water issues that are particularly sensitive to consultation 
fatigue.Strategic planning can help to identify which actors should be involved and when.It is important to findthe appropriate balance between inclusiveness and empowerment of participants.Therefore, methods and processes adopted to identify who should be involved must bebased on a clear understanding of the advantage and inconvenience of involving a largeor small number of stakeholders with clear reasons for selection, and be as transparent aspossible (OECD, 2015).

Thomas (2004) suggested that; In public policy and management decision makingprocesses related to complex water management and planningproblems, three main groups of stakeholders could be represented: 1) scientists, external experts or researchers;2) governments, policy makers and managers; and 3) general public. Participative modeling, where the role of thescientists, engineers and technical experts is to provide supportand requested knowledge for the local stakeholders and otherdecision makers to formulate, structure, build and use a model orseveral models (i.e. the 'meta-objects') oftheir messy problem situation (Figure 5). The participatory modeling processconstitutes a series of collective decision cycles of problemidentification, problem definition, model structure and hypotheses, potential solutions, scenarios and their evaluation, culminatingin final collective decisions on planned actions forimplementation.In participatorymodelingthe stakeholders involved in the collective problem vision, model design and alternative design, phasesbefore making their final collective choices. It is hypothesized that participatory modeling; helps to examine the real underlying problems; increases trust, appropriation and understanding of the models created, as assumptions and uncertainties are more likely to be explicitly identified and discussed; generates greater creativity and innovation; leads to an improved ability to respond to change through enhancing social capacity, adaptability, flexibility and resilience; leads to greater individual and social learning; produces richer and more realistic action plans; and provides a greater chance of adoption or implementation of problem management alternatives.

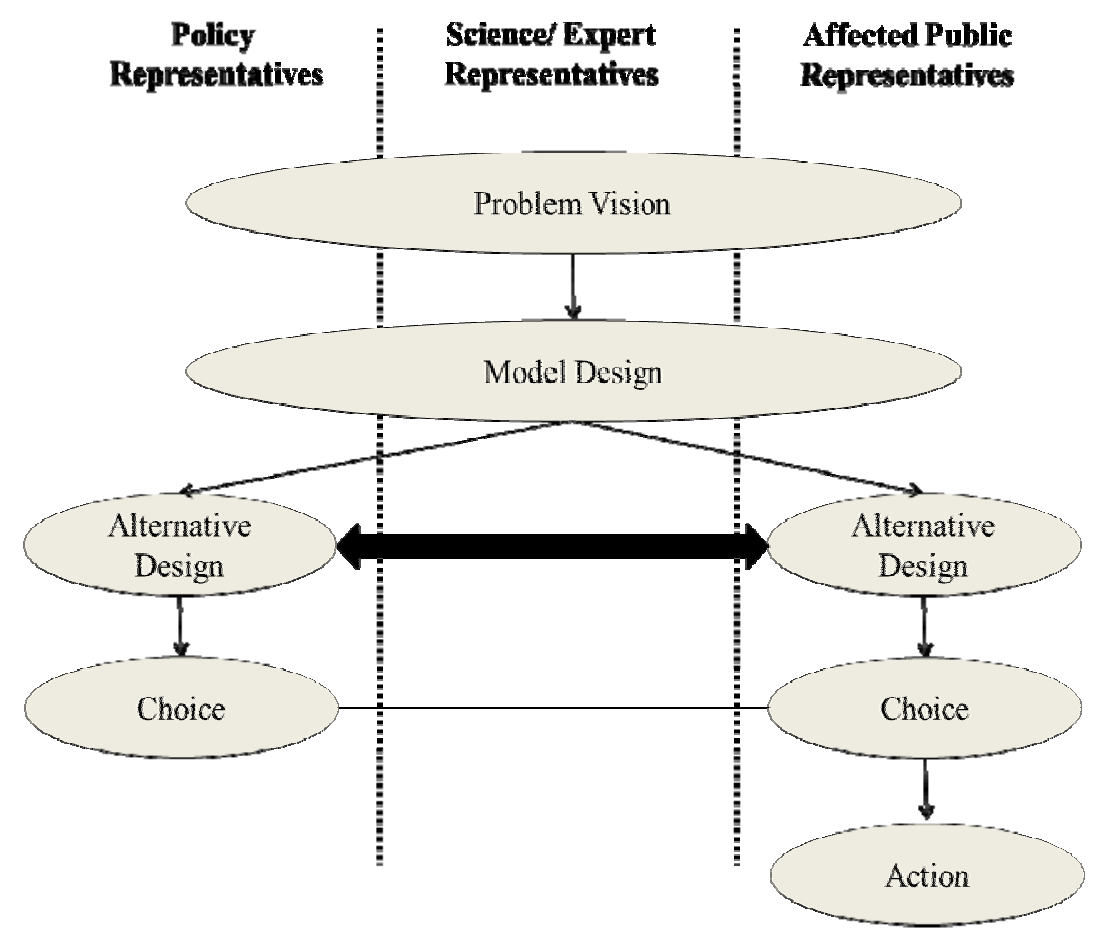

\section{No pre-defined problem exists. The worldview, problem definition, model design, solution design and final choice between alternatives are collaboratively constructed through a series of collective decision cycles. Feedback loops between stages are likely.}

Figure 5. Participatory modeling in water sector (Daniell et al., 2010)

The modelling stages in which stakeholder may be engaged during a participatory monitoring exercise are (Hare, 2011):

- Data Collection: where stakeholders participate in the collection of data to support model definition or later parameterization. Typically this could include participatory monitoring and surveys, or merely a request to contribute data.

- Model Definition: where stakeholders provide input to decisions regarding components of the model to be included, model assumptions, scenario variables, or user requirements. Stakeholder knowledge can be elucidated via interviews, card sorting, cognitive mapping, design workshops, etc. 
- Model Construction: where stakeholders actively participate in the technical activities to determine the ontology of the model, and a working model is constructed.

- Model Verification/Validation: where either model components (verification) or outputs (validation) are checked to ensure that model is operating as intended. Methods include show and tell workshops, focus group discussions, questionnaires, etc.

- Model Use: where stakeholders use the model (either directly or indirectly, refer above). Here distinction can be made between:

- Use that involves providing model inputs (e.g. scenarios/policy contexts)

- Actual use of the model, where its outputs are analyzed and discussed

- The special case where stakeholders become part of the model through acting in gaming simulations (Bots \& van Daalen, 2008).

- Alternatives/Strategies Development: where stakeholders are actively involved in the formulation of alternative strategies or measures to deal with the problem being modelled. Again, focus group discussions and workshops could be used.

Based upon the above timing of stakeholder involvement, each of the participatory modelling approaches will also then be classified into one of the four generalised forms(Hare, 2011):

- Front- and Back-End (FABE) form: where stakeholders are involved in at least one modelling stage both before and after (but not including) 'Model Construction' activities.

- Co-construction form: where stakeholders participate in the 'Model Construction' stage.

- Front-end (FE) form: where stakeholders participate in any number of modelling stages prior to 'Model Construction'.

- Back-end (BE) form: where stakeholders participate in any number of modelling stages following 'Model Construction'.

\section{Effective participatory processes}

There are many ways to define and characterize stakeholder work. The steps outlined below offer a simple model that can help organize and describe objectives, techniques and critical issues and questions that practitioners face (Sherry, 2001):

Assessment and planning: This step involves identifying key stakeholders (who cares?), determining the nature of the water resource issues (what matters?), recognizing potential conflicts and a range of optional solutions (what might be possible?), and recognizing what level of engagement is appropriate (how do we get there?). It is also wise to assess the technical complexity of the situation, the data and analysis available (or needed), and if there are adequate resources and time to collect and deliver relevant information. This initial stage can be intuitive and quite modest, involving brief background research, some critical thinking and a few conversations. Or it can be formal and elaborate, involving stakeholder interviews and comprehensive situation assessment. The most common tools for assessing stakeholder opinions are individual interviews, group interviews, or focus groups or surveys.

Organization and process design: The products of the organizational phase might include a flow chart illustrating thetime line, tasks, milestones, and sequence of interactions. It might also include a charter and/or set of ground rules. The initial process design should reflect as muchof the overall effort as possible. Invariably, however, there will be diversions, changes, andrevisions. A well-organized process requires adequate time and funding and needs a thoughtful communications strategy.

Education: Water resources management involves complex hydrologic issues relying on extensive data, technical methodologies, and models. It also involves technical and policy assumptions and risk analysis. This type of information requires considerable education and study. At the beginning of a project or plan, a mutual education phase allows for a complete review of the history, context, and legal or statutory constraints, as well as development of a common understanding of the problem to be solved. Later in the process, mutual education also creates a framework for future discussions, including the range and order of issues and alternatives to be addressed, an understanding of each stakeholder's interests, and development of a common technical information base.

An interest-based approach to developing goals, ideas and options:The key to building consensus is helping stakeholders share their interests- and understand and incorporate the interests of others. Interests are the underlying needs, concerns, and hopes that give rise to positions. A fundamental principle in collaboration is to help stakeholders define their underlying interests and make these known in a non-judgmental way to all participants. Reaching conceptual agreements early in a process demonstrates the value of the collaboration and establishes a foundation. The easiest first victory is to agree on a charter and ground rules. Next on the list might be defining the problem to be resolved or the questions to ask. However, to move toward solutions, agreement 
on broad principles or goalscan provide the foundation for success. Goals that can expressin a few sentences the basic aspirations of the group are a powerful starting point.

Building agreements: Even after looking objectively at a problem through mutual education, and gaining exposure to alternative solutions through idea generation, rarely will all group members quickly agree on one answer. The obvious solution often looks different to each stakeholder. A 'trial balloon', or a tentative proposed solution that is floated for feedback, is a useful tool for assisting groups to move toward convergent thinking. A single person or a group of stakeholders can create the proposal for the group to evaluate. Using trial balloons is an iterative process, where each proposal is criticized and modified to better meet interests. The group's job is to actively consider the trial balloon, determine if there are any data gaps, and reach agreement- or reshape, reinvent, or create a new trial balloon.

Sustainable solutions: For an agreement to be sustainable, the parties need to know that their issues are going to be followed through and that commitments will be met. For example, if an environmental group seeks higher levels of water conservation in the future, they will expect assurances that actions are going to occur and that periodic monitoring will demonstrate levels of compliance. Building-in assurances (give participants comfort that their interests will be met), monitoring, funding (provide on-going information to enable stakeholders to see that elements of the agreement are being met) and an on-going venue for discussion, evaluation and adaptation (allows projects to move forward in the face of uncertainty) are essential to long-term success.

In any stakeholder interaction, large or small, short term or long, some form of these phases plays out, either deliberatively or organically. For a comprehensive stakeholder process, each step is followed deliberately to ensure an organized and effective approach. But even for a single meeting, the discipline of assessing the situation, planning and organising, educating stakeholders around issues, and then (and only then) negotiating or seeking agreement is a useful sequence.

\section{Conclusion}

Public policy making is trending away from the old "top-down hierarchical model", which exerts sovereign control over the people and civil society, to a more transparent and holistic model that involves public, non-state actors (private sector and not-for-profit organisations). The water sector has undergone this change; the traditional role of "governments" as the single decision-making authority has been replaced by multi-level, polycentric governance. This transition acknowledges the important role that stakeholders from different institutional settings can contribute to water management. This shift is demonstrated by the development and use of international hard and soft instruments for stakeholder engagement. Understanding how stakeholder engagement has evolved, as well as the key concepts and definitions that underlie it, is crucial to identifying inherent challenges and policy solutions.Naturally, it is of interest to establish the most appropriate means to incorporate stakeholder participation in project planning and computer-based modelling processes to maximise the potential benefits, minimise the negative consequences, and restrict or mitigate the impacts of any limiting conditions. It is only by doing so that the 'risks' of involving stakeholders in participatory management activities will become more acceptable to water managers, experts and decision-makers alike, and the demand for such approaches will increase. To do so, however, relies upon focussing attention upon the performance of participatory management exercises in achieving these aims.Public/ Stakeholder participation allows the planning team to understand the problems, issues, and possible solutions from the perspectives of the various interests.There are three primary goals of public participation: 1) Credibility: An open and visible decisionmaking process accessible to all on an equal basis makes the planning process credible to groups with diverging points of view; 2) Identifying Public Concerns and Values: various groups have different points of view and values, they will evaluate any proposed action from different perspectives; 3) Developing a Consensus: An implication of the many divergent points of view is that there is no one philosophy that can guide the planning team's decisions. Consensus must be formed on an issue by issue basis. Public participation provides a process for evolving such consensus.

\section{Reference}

[1] Arnstein, Sh. 1969. A ladder of citizen participation, Journal of the American Institute of Planners 35.4: 216-224.

[2] Beierle, T. C. 2000. Public participation in environmental decisions: an evaluation framework using social goals. Discuss. Pap 99e06, Resour. of the Future, Washington. D. C.

[3] Beierle, T. Cayford, C. 2002. Democracy in Practice: Public Participation in Environmental Decision, report 158 pp. Resources of the Future, Washington. D. C.

[4] Bernoff, J and Li, Ch. 2010. Social technographics revisited - mapping online participation.

[5] Blackstock, K.L. Kelly, G.J. Horsey, B.I. 2007. Developing and applying a framework to evaluate participatory research for sustainability. Ecological Economics 60, 726e742.

[6] Bots, P. W. G.and van Daalen, C. E. 2008. Participatory model construction and model use in natural resource management: A framework for reflection. Systemic Practice and Action Research, 21(6), 389-407.

[7] Bryson, J. M. 2004. What to do when Stakeholders matter. Public Management Review, 6(1), 21-53.

[8] Buchecker, M. Hunziker, M. Kienast, F. 2003. Participatory landscape development: overcoming social barriers to public involvement. Landscape and Urban Planning 64, 29e47.

[9] Buchy, M. Hoverman, S. 2000. Understanding public participation in forest planning: a review. Forest Policy and Economics 1, $15 \mathrm{e} 25$. 
[10] Buttoud, G. Yunusova, I. 2002. A “mixed model” for the formulation of a multipurpose mountain forest policy ; theory vs. practice on the example of Kyrgyzstan. Forest Policy \& Economics 4 (2), 149e160.

[11] Cardwell, H. Langsdale, S. Stephenson, K. 2009. The Shared Vision Planning Primer: How to incorporate computer aided dispute resolution in water resources planning (pp. 38).

[12] Carter, J. Gronow, J. 2005. Recent experience in collaborative forest management: a review paper. CIFOR Occasional paper No.43, CIFOR, Bogar, Indonesia. 48 pp.

[13] Charles E. Y and Kenneth D. O. 1996. Planning manual. IWR Report 96-R-21.

[14] Creighton, J. L. 1986. Managing Conflict in Public Involvement Settings: Training Manual for Bonneville Power Administration, Pablo Alto, California. Creighton and Creighton, Los Gatos, CA.

[15] D’Aquino, P. 2009. La participation commeélémentd'unestratégieglobaled'intervention: l'approche « gestionautonome progressive ». Cahiers / Agricultures 8(5):433-440.

[16] Daniell, K. A. White, I. Ferrand, N. Ribarova, I. S. Coad, P. Rougier, J. Hare, M. Jones, N. A., Popova, A. Rollin, D. Perez, P. and Burn, S. 2010. Co-engineering participatory water management processes: theory and insights from Australian and Bulgarian interventions. Ecology and Society, 15 (4).

[17] Davidson, S.1998. Spinning the wheel of empowerment. In: Planning. Vol. 1262.

[18] Davies, T. 2009. Can social networks bridge the participation gap?.

[19] Davies, T. 2011. Rethinking Responses To Children And Young People’s Online Lives.

[20] De Backer, K and Jans, M. 2002. Youth (-work) and social participation. Elements for a practical theory.

[21] DFID-CSO. 2010. Youth Working Group. Youth participation in development.

[22] Driskell, D and Neema, K. 2009. Creating Space for Participation: The Role of Organizational Practice in Structuring Youth Participation. In: Community Development, Vol. 40 .

[23] Driskell, D. 2002. Creating better cities with children and youth - a training manual.

[24] Duram, L. A. Brown, K.G. 1999. Assessing public participation in US watershed planning initiatives. Society \& Natural Resources 12 , $455 \mathrm{e} 467$.

[25] Enserink, B. Hermans, L. Kwakkel, J. Thissen, W. Koppenjan, J. and Bots, P. 2010. Policy Analysis of Multi-Actor Systems. The Hague, Netherlands: Lemma.

[26] Fletcher, A. 2003. Purpose, empowerment and the experience of volunteerism in community. Freechild Project.

[27] Fliervoet, J. M. Geerling, G. W. Mostert, E. Smits, A. J. M. 2016. Analyzing Collaborative Governance Through Social Network Analysis: A Case Study of River Management Along the Waal River in The Netherlands. Environmental Management. February 2016, Volume 57, Issue 2, pp 355-367.

[28] Fogg, B. J. 2010. The Behavior Grid: 15 Ways Behavior Can Change.

[29] Fogg, Ch. and Eckles, D .2007. The Behavior Chain for Online Participation: How Successful Web Services Structure Persuasion.

[30] Francis, M and Lorenzo, R. 2002. Seven Realms Of Children’s Participation.

[31] Fung, A. 2006. Varieties of participation in complex governance. Public Administration Review 66 (1):66-75.

[32] Gaventa, J. 2006. Finding the spaces for change: a power analysis. In: IDS Bulletin, 37(6).

[33] Glucker, A. N. Driessen, P. J. Kolhoff, A. andRunhaar, H. A. C. 2013. Public participation in environmental impact assessment: Why, who and how?. Environmental Impact Assessment Review, Vol. 43, November, pp. 104-111.

[34] Griffin, C. B. 1999. Watershed councils: an emerging form of public participation in natural resource management. Journal of the American Water Resources Association 35 (3).

[35] Grimble, R. and Chan, M. 1995. Stakeholder analysis for natural resource management in developing countries. Some practical guidelines for making management more participatory and effective. Natural Resources Forum, Vol.19 (2), pp.113-124.

[36] Grimble, R. Wellard, K. 1997. Stakeholders methodologies in natural resourcesmanagement: a review of principles, contexts, experiences and opportunities.Agricultural Systems 55 (2), $173 e 193$.

[37] Hare, M. 2011. Forms of participatory modelling and its potential for widespread adoption in the water sector. Environmental Policy and Governance, 21(6), 386-402.

[38] Hart, R. 1992. Children’s participation: from tokenism to citizenship. Essay for UNICEF (Innocenti Essay N 4).

[39] Indo-Swiss Participative Watershed Development Programme (ISPWDK). 2005. Empowering the People: Experience with Village Development Societies in Promoting Local Governance. In: ISPWDK Programme Series, vol. 1. Intercooperation Delegation, Hyderabad, India.

[40] International Association of Public Participation (IAP2). 2007. IAP2 Spectrum of Public Participation.

[41] International Association of Public Participation (IAP2). 2009. International Association for Public Participation.

[42] Irvin, R. A. Stansbury, J. 2004. Citizen participation in decision making: is it worth the effort? Public Administration Review 64 (1), $55 \mathrm{e} 65$.

[43] IWR. 2002. Public Involvement and Teaming in Planning, a Training Workbook. http://www.iwr.usace.army.mil/iwr/plannersweb/docs/pubinvolv/finalworkbook.pdf,accessed December 14, 2005.

[44] Junker, B. Buchecker, M. Müller-Böcker, U. 2007. Objectives of public participation: which actors should be involved in the decision making for river restorations. Water Resources Research 43 (10), W10438.

[45] Kenney, D. S. McAllister, S.T. Caile, W. H. Peckham, J. S. 2000. The New Watershed Source Book: a Directory and Review of Watershed Initiatives in the Western United States. Natural Resources Law Center, University of Colorado School of Law.

[46] Kessler, B. L. 2004. Stakeholder Participation: A Synthesis of Current Literature.National Oceanic and Atmospheric Administration.

[47] Knight, T. A. Cowling, R. M. Campbell, B. 2006. An operational model for implementation conservation action. Conservation Biology 20 (2), 408e419.

[48] Konisky, D. M. Beierle, T. C. 2001. Innovation in public participation and environmental decision making: examples from the great lakes region. Society and Natural Resources 14 (9), 815e826.

[49] Lardner, C. 2001. Youth participation - a new model. Edinburgh: Youth Social Inclusion Partnership.

[50] Leach, W. D. Pelkey, N. W. 2001. Making watershed partnerships work: a review of the empirical literature. Journal of Water Resources Planning and Management 127 (6), 378e385.

[51] Leach, W. D. Pelkey, N. W. Sabatier, P. A. 2002. Stakeholders partnerships as collaborative policymaking: evaluation criteria applied to watershed management in California andWashington. Journal of Policy Analysis and Management 21 (4), 645e670.

[52] Lowndes, V. and Pratchett, L. 2006. CLEAR: Understanding Citizen Participation in Local Government.

[53] Luyet, V. 2005. A Framework for the Participative Process in a Large EnvironmentalProject. Case study: the 3rd Rhone river correction. PhD thesis Nr 3342, SwissFederal Institute of Technology, Lausanne, Switzerland.

[54] MacArthur, J. 1997. Stakeholder analysis in project planning: origins, applications and refinements of the method. Project Appraisal, Vol.12(4): December 1997, pp.251-265.

[55] Martín, P. 2010. E-Participation at the local level: the path to collaborative democracy. 
[56] Mayfield, R. 2006. Power law of participation.

[57] Miettinen, R. and Virkkunen, J. 2005. Epistemic objects, artefacts and organizational change. Organization12(3):437-456.

[58] Moote, M. A. Mcclaran, M. P. Chickering, D. K. 1997. Theory in practice: applying participatory democracy theory to public land planning. Environmental Management 21 (6), 877e889.

[59] Mostert, E. 2003. The challenge of public participation. Water Policy, 5(2), 179-197.

[60] Mostert, E. 2006. Participation for sustainable water management. Sustainable management of water resources. Edward Elgar, Cheltenham, UK.

[61] Nandalal, K. D. W. and Simonovic, S. P. 2003. State-of-the-Art Report onSystems Analysis Methods for Resolution of Conflicts in Water ResourcesManagement. A report prepared for division of water sciences UNESCO:UNESCO-IHP.

[62] NCVO and IVR. 2009. Pathways through Participation Project : Understanding participation - a literature review.

[63] New Zealand State Service. 2007. Participation 2.0 Model. In: Guide to Online Participation. Resources - Glossary.

[64] ODA. 1995. Guidance note on how to do stakeholder analysis of aid projects and programmes. British Overseas Development Administration, Social Development Department. July 1995.

[65] OECD, 2001. Citizen as Partners: Information, Consultation and Public Participation in Policy Making. OECD Publishing, Paris.

[66] OECD. 2012. OECD Environmental Outlook to 2050: The Consequences of Inaction, OECD Publishing, Paris.

[67] OECD. 2015. Stakeholder Engagement for InclusiveWater Governance, OECD Studies on Water, OECD Publishing, Paris.

[68] Pahl-Wostl, C. 2002. Towards sustainability in the water sector: the importance of human actors and processes of social learning. Aquatic Sciences 64, 394e411.

[69] Palmer, R. N. Cardwell, H. E. Lorie, M. A. andWerick, W. 2013. Disciplined Planning, Structured Participation, and Collaborative Modeling - Applying Shared Vision Planning to Water Resources Journal of the American Water Resources Association.

[70] Pereira, A. G., J.-D. Rinaudo, P. Jeffrey, J. Blasques, S. Corral Quintana, N. Courtois, S. Funtowicz, and V. Petit. 2003. ICT tools to support public participation in water resources governance and planning: experiences from the design and testing of a multi-media platform. Journal of Environmental Assessment Policy and Management 5(3):395-420.

[71] Reed, M. S. 2008. Stakeholder participation for environmental management: a literature review. Biological Conservation 141, $2417 \mathrm{e} 2431$.

[72] Renn, O. Webler, T. Wiedermann, P. 1995. Fairness and competence in citizen participation: evaluating models for environmental discourse. Technology, Risk and Society 10.

[73] Richards, C. Blackstock, K. L. Carter, C. 2004. Practical Approaches to Participation. In: SERP Policy Brief, vol. 1. Macaulay Institute, Aberdeen.

[74] Rist, S. Chidambaranathan, M. Escobar, C. Wiesmann, U. Zimmermann, A. 2007. Moving from sustainable management to sustainable governance of natural resources: the role of social learning processes in rural India, Bolivia and Mali. Journal of Rural Studies 23 (1), $219 \mathrm{e} 237$.

[75] Rowe, G. Frewer, L. J. 2000. Public participation methods: a framework for evaluation. Science Technology \& Human Values 25 (1), 3 e29.

[76] Sabatier, P.A. Vedlitz, A. Foch, W. Lubell, M. Matlock, M. 2005. Swimming Upstream: Collaborative Approaches to Watershed Management. In: American and Comparative Environmental Policy. MIT Press, 328 pp.

[77] Sherry, S. 2001. Spring Training for the Center for Collaborative Policy. Sacramento State University.

[78] Shier, H. 2001. Pathways to participation: openings, opportunities and obligations. In: Children and Society Vol 15.

[79] Shier, H. 2010. Pathways to Participation Revisited: learning from Nicaragua’s child coffee-workers.

[80] Smith Korfmacher, K. 2001. The politics of participation in watershed modelling. Environmental Management 27 (2), $161 \mathrm{e} 176$.

[81] Thomas, R. L. 2004. Management of freshwater systems: the interactive roles of science, politics and management, and the public. Lakes and Reservoirs: Research and Management, 9(1), 65-73.

[82] Tippett, J. Handley, J. F. Ravetz, J. 2007. Meeting the challenges of sustainable development e a conceptual appraisal of a new methodology for participatory ecological planning. Progress in Planning 67, 9e98.

[83] Treseder, Ph.1997. Empowering children and young people: promoting involvement in decision-making.

[84] UNICEF. 2001. The participation rights of adolescents: a strategic approach. UNICEF Working Paper Series.

[85] Van Asselt, M. Mellors, J. Rijkens-Klomp, N. Greeuw, S. Molendijk, K. Jelle Beers, P. Van Notten, P. 2001. Building Blocks for Participation in Integrated Assessment: A Review of Participatory Methods. ICIS, Maastricht.

[86] Varvasovszky, Z. and Burgha, R. 2000. How to do (or not to do)...A stakeholder analysis. Health Policy and Planning, Vol.15 (3), pp.338-345.

[87] Von Korff, Y. 2005. Towards an evaluation method for public participation processes in AquaStress and NeWater: a proposal for both projects. AquaStress and NeWaterinternal working document, Sixth EU Framework Programme. Cemagref, Montpellier, France.

[88] Walker, B. Carpenter, S. Anderies, J. Abel, N. Cumming, G. Janssen, M. Lebel, L.Norberg, J. Peterson, G. D. and Pritchard, R. 2002. Resilience management in social-ecological systems: a working hypothesis for a participatory approach. Conservation Ecology 6(1): 14.

[89] Warburton, D. 2007. Making a Difference: A guide to evaluating public participation in central government.

[90] Webler, T. Tuler, S. Krueger, R. 2001. What is a good public participation process? Five perspectives from the public. Environmental Management 27 (3), 435e450.

[91] Wenmoth, D. 2006. Participation Online - the Four Cs.

[92] Werick, W. J. Whipple, W. Jr. 1994. Managing Water for Drought. In I. F. W. R. U.S. Army Corps of Engineers (USACE) (Ed.), National Study of Water Management During Drought, IWR Report 94-NDS-8.

[93] White, S. 1996. Depoliticising Development: The Uses and Abuses of Participation. Development in Practice Volume 6, Number 1, February 1996.

[94] Wicklin, R. 2010. How does participation in social media vary with age?.

[95] Wilson, G. A. 2004. The Australian Landcare movement: towards 'post-productivist' rural governance? Journal of Rural Studies 20 (4), 461e484.

[96] Wong, N. T. Zimmerman, M. A. Parker, E. A. A. 2010. Typology of youth participation and empowerment for child and adolescent health promotion. American Journal of Community Psychology. 2010 Sep;46(1-2):100-114. 